\title{
Analisis faktor-faktor yang mempengaruhi kunjungan wisatawan nusantara asal Kota Jambi ke objek wisata alam Taman Nasional Kerinci Seblat (TNKS) di Kabupaten Kerinci Provinsi Jambi (pendekatan biaya perjalanan travel cost approach)
}

\author{
*Cintya Anita; Muhammad Safri; Nurhayani \\ Prodi Ekonomi Pembangunan, Fakultas Ekonomi dan Bisnis, Universitas Jambi \\ *E-mail korespondensi: cintyaanita28@gmail.com
}

\begin{abstract}
The purpose of this study to determine the development of visiting archipelago tourists from Jambi City to TNKS, factors that influence, and willingness to pay. The data used are secondary from BPS and primary data from questionnaires and direct interviews with a sample of 39. The sampling methods used was purposive sampling. The data an analysis tools are used is descriptive and quantitave analysis's with multiple linear analysis. The resulth of this study indicate, the average development of tourists visiting the archipelago is $24,82 \%$, the average hotel rates is $5,70 \%$, the average number of private vehicles in Jambi City is 22,64\%, the average productive populasi of Jambi City is 1,8\%. The simultaneous all variables have a positive and signifikan effect. While partially the average hotel rates in Kerinci has a negative and insignificant effect, while the number of private vehicles in Jambi City and productive populasi of Jambi City have a positive and significant. Willingness to pay/WTP recorded at Rp. 4.026.375,with an average of Rp. 2.647,- per person.
\end{abstract}

Keywords: Average Hotel Rates, Number of Private Vehicles, Productive Population, Number of Nusantara Tourist Visits (WTP).

\begin{abstract}
Abstrak
Tujuan penelitian ini untuk mengetahui perkembangan kunjungan wisatawan nusantara Kota Jambi ke TNKS, faktor-faktor yang mempengaruhinya, nilai kesediaan membayar. Data yang digunakan sekunder diperoleh dari BPS dan data primer diperoleh dari kuisoner wawancara langsung dengan jumlah sampel 39. Metode purpose sampling, alat analisis deskripsitf dan kuantitatif dengan analisis regresi linier berganda. Hasil penelitian ini rata-rata perkembangan kunjungan wisatawan nusantara sebesar $24,82 \%$, rata-rata tarif hotel Kerinci sebesar 5,70\%, rata-rata jumlah kendaraan pribadi Kota Jambi sebesar 22.64\%, rata-rata jumlah penduduk produktif Kota Jambi sebesar 1,8\%. Secara simultan semua variabel berpengaruh positif dan signifikan. Sementara secara parsial rata-rata tarif hotel Kerinci berpengaruh negatif dan tidak signifikan. Sedangkan jumlah kendaraan pribadi Kota Jambi dan jumlah penduduk produktif Kota Jambi berpengaruh positif dan signifikan. Nilai kesediaan membayar/WTP tercatat sebesar Rp. 4.026.375,- dengan rata-rata sebesar Rp. 2.647,- per orang.

Kata Kunci: Rata-Rata Tarif Hotel, Jumlah Kendaraan Pribadi, Jumlah Penduduk Produktif, Jumlah Kunjungan Wisatawan Nusantara dan Nilai Kesediaan Membayar (WTP).
\end{abstract}




\section{PENDAHULUAN}

Dunia pariwisata merupakan sektor yang memiliki pengaruh penting dalam perkembangan dan pembangunan suatu negara untuk dikembangkan sebagai salah satu sumber pendapatan daerah. Program pengembangan dan pendayagunaan sumber daya dan potensi pariwisata daerah diharapkan dapat memberikan sumbangan bagi pembangunan ekonomi. Secara luas pariwisata dipandang sebagai kegiatan yang mempunyai multidimensi dari rangkaian suatu proses pembangunan. Pembangunan sektor pariwisata menyangkut aspek sosial budaya, ekonomi dan politik (Spillane, 2004).

Perkembangan pariwisata juga mendorong dan mempercepat pertumbuhan ekonomi. Kegiatan pariwisata menciptakan permintaan, baik konsumsi maupun investasi yang pada gilirannya akan menimbulkan kegiatan produksi barang dan jasa. Selama berwisata, wisatawan akan melakukan belanjaannya, sehingga secara langsung menimbulkan permintaan Tourism Final Demand pasar barang dan jasa. Selanjutnya Final Demand wisatawan secara tidak langsung menimbulkan permintaan akan barang modal dan bahan baku Investment Derived Demand untuk berproduksi memenuhi permintaan wisatawan akan barang dan jasa tersebut. Dalam usaha memenuhi permintaan wisatawan diperlukan investasi di bidang transportasi dan komunikasi, perhotelan dan akomodasi lain, industri kerajinan dan industri produk konsumen, industri jasa, rumah makan restoran dan lain-lain.

Majunya industri pariwisata suatu daerah sangat bergantung kepada jumlah wisatawan yang datang. Jumlah penduduk juga merupakan hal penting bagi kunjungan wisata alam, kelompok umur 15-64 tahun merupakan jumlah penduduk produktif yang keinginan berwisata alamnya tinggi dibandingkan kelompok umur 15 tahun kebawah, karena itu harus ditunjang dengan peningkatan pemanfaatan Daerah Tujuan Wisata (DTW) sehingga industri pariwisata akan berkembang dengan baik. Negara Indonesia yang memiliki pemandangan alam yang indah sangat mendukung bagi berkembangnya sektor industri pariwisata di Indonesia.

Di Provinsi Jambi terdapat beberapa objek pariwisata alam ecotourism yang memiliki potensi dan dapat dikembangkan sebagai lokasi tujuan wisata sambil melakukan kegiatan penelitian dan atau minat khusus lainnya, yang ditandai beberapa taman nasional yang dimiliki Provinsi Jambi. Wilayah Taman Nasional Kerinci Seblat merupakan Taman Nasional yang berada di 4 Provinsi yaitu Sumatera Barat, Jambi, Bengkulu, dan Sumatera Selatan. Masuk ke dalam 9 Kabupaten, 43 Kecamatan dan 134 Desa. Karena ingin mengembangkan potensi wisata alam di Jambi menjadi kekuatan nyata wilayah Jambi dipilih Kota Jambi dengan pertimbangan bahwa Kota Jambi dari sisi ekonomi wilayah merupakan wilayah yang memiliki hirarki tertinggi (dari sisi jumlah dan sisi prasarana atau infrastruktur) diantara Kabupaten Kota yang ada di Kabupaten Provinsi Jambi. TNKS salah satu taman nasional yang ada di Provinsi Jambi dan relatif sudah berkembang dibandingkan taman nasional lainnya (Taman Nasional Bukit Tiga Puluh, Taman Nasional Bukit Dua Belas, dan Taman Nasional Berbak).

TNKS terdapat beberapa flora dan fauna unik dan spesifik yang menarik untuk dikunjungi oleh pariwisatawan. Secara umum tumbuh lebih kurang 4.000 jenis flora dari 63 famili dan untuk jenis fauna yang ada dalam Taman Nasional Kerinci Seblat tercatat 42 jenis mamalia, 10 jenis reptil, 6 jenis ampibi, 306 jenis burung dari 49 famili serta 8 jenis burung endemik. Keberadaan objek wisata TNKS ini sayangnya relatif jauh dan sudah barang tentu membutuhkan biaya transportasi wisatawan dari Jambi untuk datang kesana. Jarak tempuh dari wilayah yang beheirarki tinggi memiliki jenis dan jumlah sarana dan prasarana pariwisata yang lebih banyak (Kota Jambi) dan ke 
wilayah yang berhierarki lebih rendah (Kabupaten Kerinci) merupakan salah satu faktor yang dianggap besar pengaruhnya terhadap jumlah kunjungan wisatawan nusantara ke lokasi pariwisata TNKS.

Kota Jambi memiliki kontribusi sektor industri perdagangan dan jasa-jasa atas dasar kehidupan masyarakat yang majemuk dan banyaknya mereka di industri perdagangan serta relatif belum adanya objek wisata alam yang memadai di Kota Jambi, warga Jambi akan memilih objek wisata yang ada di daerah lain untuk menghilangkan kejenuhan dari rutinitas pekerjaan sehari-hari. Bagi para wisatawan yang suka pariwisata, selain beberapa tempat desa yang memberikan banyak panorama indahnya, ada salah satunya yaitu Kersik Tuo sebuah desa yang berada di wilayah Kabupaten Kerinci. Desa ini menjadi salah satu gerbang utama menuju Gunung Kerinci. Kersik Tuo merupakan jalur resmi yang paling banyak diminati para pendaki, karena lebih mudah dibandingkan Solok. Selain itu bisa menikmati panorama desa dengan latar pemandangan Gunung Kerinci. Di desa Kersik Tuo terdapat beragam basecamp pendakian yang buka 24 jam. Sambil istirahat dan menyiapkan barang, bisa mencari guide atau porter pendakian.

Untuk menikmati keindahan dapat pula dilakukan dengan melihat nilai kesediaan membayar masyarakat Willingness To Pay/WTP untuk usaha perlindungan lingkungan. Willingness To Pay/WTP atau keinginan membayar sebagai jumlah yang dapat dibayarkan seorang konsumen untuk memperoleh suatu barang dan jasa. Hal ini dapat ditunjukkan dengan keindahan alam yang telah dinikmati berapakah pariwisata ingin membayar keindahan alam yang dinikmati tersebut tanpa memikirkan harga yang terlalu mahal, sehingga semua kalangan dapat memberikan pendapat dengan jumlah interval yang telah disediakan bagi para peneliti yang ingin melakukan penelitian atau kegiatan lainnya.

\section{METODE}

Metode yang digunakan dalam penelitian ini adalah metode deskriptif dan kuantitatif. Data yang digunakan dalam penelitian ini adalah data sekunder yang diperoleh dari BPS dan primer yang diperoleh dari kuisoner. Populasi dalam penelitian ini adalah seluruh wisatawan nusantara asal Kota Jambi yang berkunjung ke TNKS Desa Kersik Tuo yang berjumlah 350 pengunjung selama satu bulan. Metode sampling yang digunakan adalah purposive sampling. Pengambilan sampel dalam penelitian ini menggunakan rumus slovin dengan tingkat kesalahan 15\%, yaitu 39 responden. Alat analisis yang digunakan yaitu regresi linear berganda. Model persamaannya adalah sebagai berikut (Ghozali, 13):

Keterangan:

$$
\hat{Y}_{i}=\beta_{0}+\beta_{1} X_{1}+\beta_{2} X_{2}+\beta_{3} X_{3}+e_{i}
$$

$$
\begin{array}{ll}
\hat{\mathrm{Y}}_{\mathrm{i}} & =\text { Kunjungan wisatawan nusantara asal Kota Jambi (wisnus) } \\
\beta_{0} & =\text { Konstanta } \\
\beta_{1,2,3} & =\text { Koefisien garis regresi } \\
\mathrm{X}_{1} & =\text { Rata-rata rarif hotel Kabupaen Kerinci } \\
\mathrm{X}_{2} & =\text { Jumlah kendaraan pribadi Kota Jambi } \\
\mathrm{X}_{3} & =\text { Jumlah penduduk produktif Kota Jambi } \\
\mathrm{e}_{\mathrm{i}} & =\text { Error/variabel pengganggu }
\end{array}
$$

Selanjutnya untuk menjawab tujuan ketiga penelitian digunakan analisis/pendekatan deskriptif berupa pertanyaan hipotetis kepada para pengunjung TNKS di Kabupaten Kerinci tentang nilai kesediaan membayar/WTP.

$\mathrm{WTP}=\mathrm{f}($ Jasa wisata alam lingkungan alami) 
Dimana:

WTP $=$ Nilai kesediaan membayar responden

\section{HASIL PENELITIAN DAN PEMBAHASAN}

Perkembangan kunjungan wisatawan nusantara asal Kota Jambi ke TNKS dari tahun ke tahun terus berfluktuasi. Gejala naik turunnya kunjungan wisatawan nusantara asal Kota Jambi disebabkan oleh berbagai faktor yang memiliki keterkaitan terhadap jumlah kunjungan wisatawan nusantara asal Kota Jambi ke TNKS Kerinci.

Perkembangan kunjungan wisatawan nusantara asal Kota Jambi

Perkembangan kunjungan wisatawan nusantara asal Kota Jambi ke objek wisata alam TNKS di Kabupaten Kerinci dapat dilihat pada diagram berikut:

Diagram 1. Perkembangan kunjungan wisatawan nusantara asal Kota Jambi ke objek wisata alam TNKS di Kabupaten Kerinci Tahun 1998-2017

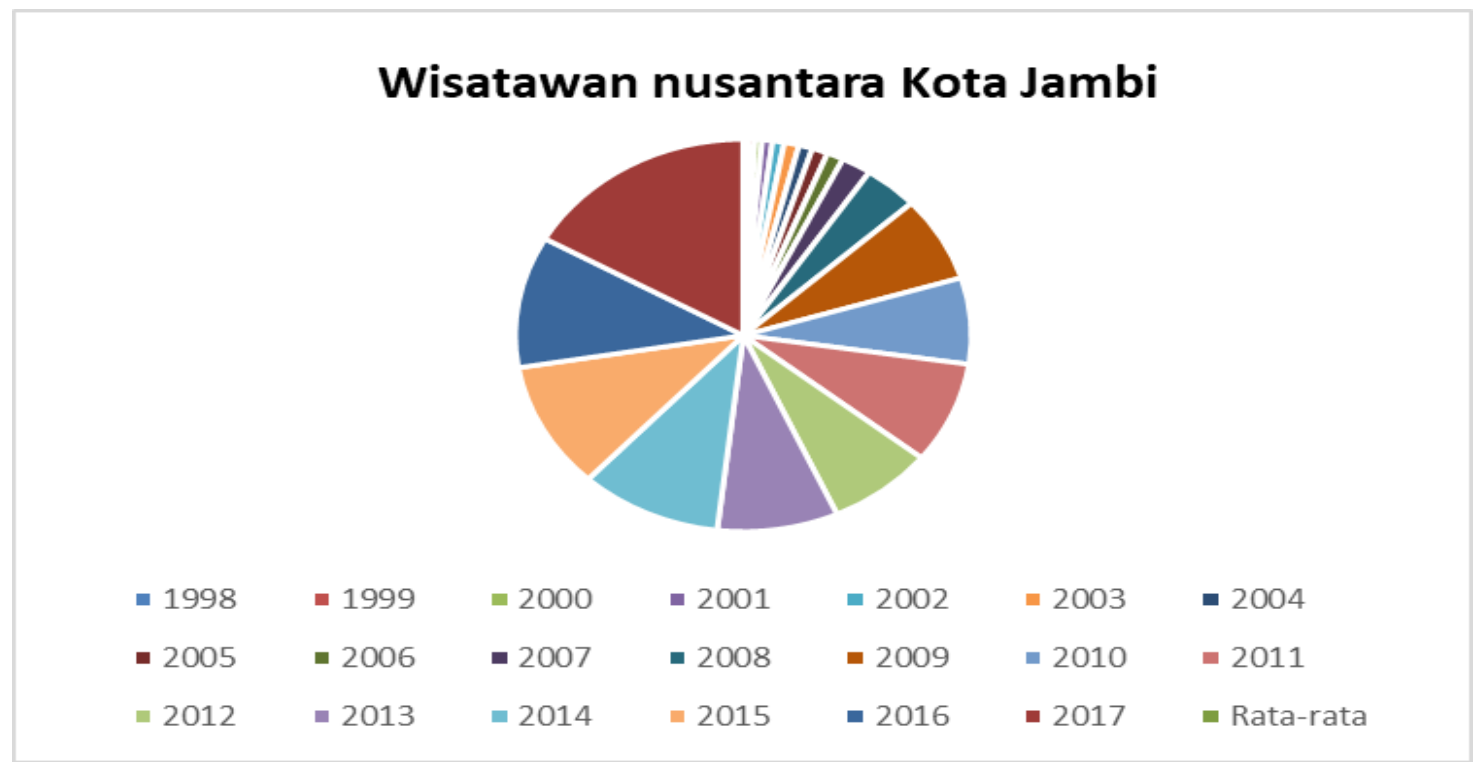

Sumber: Dinas Kebudayaan dan Pariwisata Provinsi Jambi (TNKS) 1998-2017 (data diolah)

Diagram 1 dari tahun 1998 sampai tahun 2017 kunjungan wisatawan nusantara asal Kota Jambi ke TNKS Kerinci yang terendah terjadi pada tahun 1998 sebesar 3.679 wisnus. Titik tertinggi perkembangan kunjungan wisatawan nusantara asal Kota Jambi ke TNKS Kerinci terjadi pada tahun 2007 sebesar 81,67\% dibandingkan dengan tahun 2006. Titik terendah kunjungan wisatawan terjadi pada tahun 2010 (sekitar 1,01\%). Secara keseluruhan rata-rata jumlah kunjungan wisatawan wusantara asal Kota Jambi ke TNKS Kerinci mengalami perkembangan sebesar 24,82\% per tahun dari tahun 1998 sampai dengan 2017.

Tahun 1999-2003 kunjungan wisatawan nusantara asal Kota Jambi ke TNKS Kerinci sebesar 3.894 wisnus dan tahun 2003 sebesar 9.750 wisnus atau sebesar 5,84\% dan 25,00\%. Pada tahun 2004 kunjungan wisatawan nusantara Kota Jambi ke TNKS Kerinci mengalami penurunan sebesar 9.050 wisnus atau sebesar -7,18\%. Tahun 20052009 kunjungan wisatawan nusantara asal Kota Jambi ke TNKS Kerinci mengalami peningkatan di tahun 2005 sebesar 10.500 wisnus dan 2009 sebesar 65.460 wisnus atau sebesar $16,02 \%$ dan $81,65 \%$.

Tahun 2010 hingga tahun 2015 kunjungan wisatawan nusantara asal Kota Jambi ke TNKS Kerinci mengalami fluktuasi setiap tahun, hingga tahun 2015 kunjungan wisatawan nusantara asal Kota Jambi ke TNKS Kerinci meningkat sebesar 97.660 
wisnus atau sebesar 3,75\%. Pada tahun 2017 kunjungan wisatawan nusantara meningkat sebesar 54,65\% dibandingkan keadaan tahun 2016. Kunjungan wisatawan nusantara secara keseluruhan selama 2017 sebanyak 156.777 wisnus. Memang diakui, kunjungan total 2017 ini relatif sangat kecil jika dibandingkan dengan target kunjungan wisatawan nusantara secara nasional pada tahun 2017 (19,5 juta) hanya mencapai 0,80\%.

\section{Perkembangan rata-rata tarif hotel}

Rata-rata tarif hotel merupakan suatu satuan unit yang kerap digunakan dalam industri perhotelan. Nilai yang dihasilkan merujuk kepada besaran tarif rata-rata atas kamar yang dihuni. Kunjungan wisatawan nusantara asal Kota Jambi ke TNKS Kerinci juga dipengaruhi oleh rata-rata tarif hotel di Kerinci.

Pekembangan rata-rata tarif hotel di Kabupaten Kerinci dapat dilihat pada diagram berikut:

Diagram 2. Pekembangan rata-rata tarif hotel di Kabupaten Kerinci Tahun 1998-2017

\section{Rata-rata tarif hotel Kerinci}

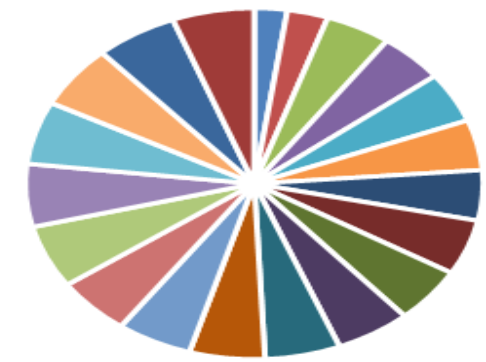

$$
\begin{aligned}
& \text { - } 1998=1999=2000=2001=2002 \quad=2003 \quad-2004 \\
& \text { - } 2005=2006 \quad-2007 \quad \text { - } 2008 \quad-2009 \quad=2010 \quad-2011 \\
& =2012=2013=2014=2015=2016=2017 \text { = }=2016 \text { Rata-rata }
\end{aligned}
$$

Sumber: Dinas Kebudayaan dan Pariwisata Provinsi Jambi (TNKS) 1998-2017 (data diolah)

Diagram 2 dapat dilihat bahwa rata-rata tarif hotel Kerinci periode tahun 19982017 cenderung meningkat setiap tahunnya. Rata-rata perkembangan tarif hotel Kerinci sebesar 5,70\%, tarif ini sebenarnya relatif tidak bisa tahun demi tahun ditingkatkan oleh karena pihak hotel biasanya mempertimbangkan daya beli para wisatawan yang datang dengan dukungan fasilitas hotel yang mampu mereka sediakan. Di Kabupaten Kerinci tidak ada hotel berbintang, hotel yang ada hanya masuk klasifikasi hotel melati.

Pada tahun 1998-1999 rata-rata tarif hotel Kerinci tahun 1998 sebesar Rp. 100.000-, per kamar dan tahun 1999 sebesar Rp. 125.000,- per kamar atau sebesar 25\%. Di tahun 2000-2004 rata-rata tarif hotel Kerinci mengalami peningkatan yang sama sebesar Rp. 200.000 per kamar atau sebesar 60\%. Tahun 2005-2006 rata-rata tarif hotel Kerinci sebesar Rp. 220.000,- per kamar atau sebesar 10\%. Tahun 2007-2011 rata-rata tarif hotel Kerinci mengalami peningkatan lagi sebesar Rp.230.000,- per kamar atau sebesar 4,55\%. Hingga tahun 2012-2017 rata-rata tarif hotel Kerinci meningkat sebesar Rp.250.000-, per kamar atau sebesar 8,70\%.

\section{Perkembangan jumlah kendaraan pribadi Kota Jambi}

Setiap tahun pertumbuhan kendaraan pribadi baik itu roda dua ataupun empat terus mengalami peningkatan yang cukup signifikan. Kunjungan wisatawan nusantara asal Kota Jambi ke TNKS Kerinci juga dipengaruhi oleh jumlah kendaraan pribadi Kota 
Jambi. Dengan adanya kendaraan pribadi dan minat berwisata maka akses untuk menuju lokasi objek wisata alam TNKS akan lebih mudah untuk di kunjungi bersama keluarga atau kerabat. berikut:

Perkembangan jumlah kendaraan pribadi Kota Jambi dapat dilihat pada diagram

Diagram 3 Perkembangan jumlah kendaraan pribadi Kota Jambi Tahun 1998-2017

\section{Jumlah kendaraan pribadi Kota Jambi}

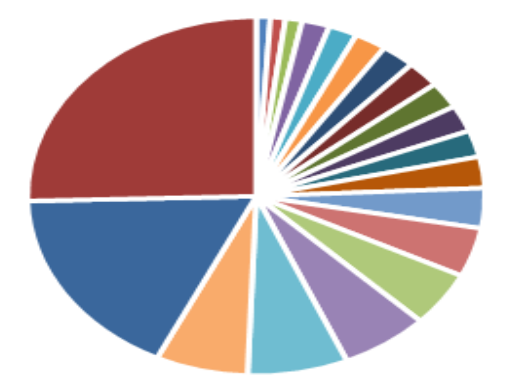

$$
\begin{array}{lllllll}
=1998 & =1999 & =2000 & =2001 & =2002 & =2003 & =2004 \\
=2005 & =2006 & =2007 & =2008 & =2009 & =2010 & =2011 \\
=2012 & =2013 & =2014 & =2015 & =2016 & =2017 & =\text { Rata-rata }
\end{array}
$$

Sumber: Data Nasional yang di olah untuk kepentingan Jumlah Kendaraan Pribadi Kota Jambi, 1998-2017 (data diolah)

Diagram 3 dapat dilihat bahwa jumlah kendaraan pribadi Kota Jambi periode tahun 1998-2017 cenderung meningkat setiap tahunnya, rata-rata jumlah kendaraan pribadi Kota Jambi sebesar 22,64\%. Peningkatan tertinggi jumlah kendaraan pribadi Kota Jambi terjadi pada tahun 2010 yaitu meningkat sebesar 50.989 unit atau sebesar 27,47\%. Sedangkan penurunan jumlah kendaraan pribadi Kota Jambi dalam kurun waktu 1998-2017 terjadi sekali, yaitu tahun 2015 sebesar 99.563 unit atau -7,94 persen dari tahun sebelumnya.

\section{Perkembangan jumlah penduduk produktif Kota Jambi}

Perkembangan jumlah penduduk produktif Kota Jambi usia 15 tahun sampai 64 tahun ini merupakan usia yang mendukung untuk melakukan kegiatan berwisata alam. Jumlah penduduk yang semakin meningkat memiliki potensi pariwisata terbesar di Kerinci Seblat.

Perkembangan jumlah penduduk produktif Kota Jambi dapat dilihat pada diagram berikut:

Diagram 4. Perkembangan jumlah penduduk produktif Kota Jambi Tahun 1998-2017 


\section{Jumlah penduduk produktif Kota Jambi}

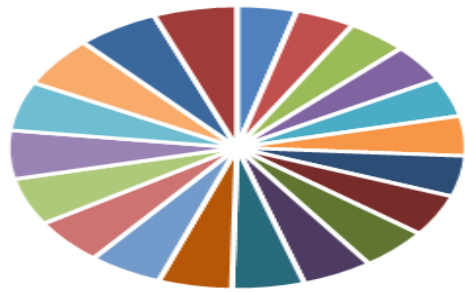

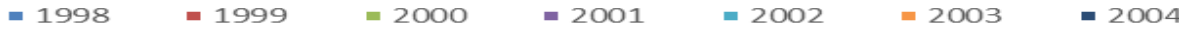

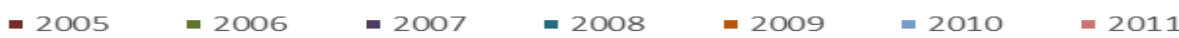

$$
\begin{aligned}
& =2012=2013=2014=2015=2016=\text { = } 2017 \text { Rata-rata }
\end{aligned}
$$

Sumber: BPS Kota Jambi Dalam Angka, 1998-2017 (data diolah)

Diagram 4 terlihat bahwa dari tahun ketahun jumlah penduduk produktif Kota Jambi berfluktuasi. Perkembangan tertinggi pada jumlah penduduk produktif Kota Jambi terjadi pada tahun 2012 dimana perkembangan jumlah penduduk produktif Kota Jambi sebesar 3,65\%. Perkembangan terendah dari diagram tersebut terjadi pada tahun 1999 dimana perkembangan jumlah penduduk produktif Kota Jambi sebesar $-0.37 \%$. Rata-rata jumlah penduduk produktif Kota Jambi sebesar 1,80\%.

Tahun 2000 jumlah penduduk sebesar 1,54\%, tahun 2001-2002 sebesar 1,03\% dan 2,62\%. Tahun 2003 meningkat sebesar 2,76\%, tahun 2004 menurun sebesar 6,64\%. Tahun 2005-2007 sebesar 2,55\%, 2,31 persen dan 2,30\%. 2008-2009 sama sebesar 2,08\%. Tahun 2010-2011 menurun sebesar 0,03\% dan 0,29\%. Tahun 2012 meningkat sebesar 3,65\%, selanjutnya tahun 2013-2017 jumlah penduduk produktif Kota Jambi mengalami fluktuasi terus menerus hingga tahun 2017 sebesar sebesar 1,68\% atau 420.288 jiwa.

Tabel 1. Hasil regresi linier berganda

Dependent Variable: Y

Method: Least Squares

Date: 07/11/19 Time: 13:38

Sample: 19982017

Included observations: 20

\begin{tabular}{crlrr}
\hline \hline \multicolumn{1}{c}{ Variable } & Coefficient & Std. Error & t-Statistic & Prob. \\
\hline C & $-261833,0$ & 41820,84 & $-6,260825$ & 0,0000 \\
X1 & $-0,189227$ & 0,141424 & $-1,338016$ & 0,1996 \\
X2 & 0,159282 & 0,054500 & 2,922586 & 0,0100 \\
\multicolumn{1}{c}{ X3 } & 0,949667 & 0,180982 & 5,247312 & 0,0001 \\
\hline \hline & & & \\
R-squared & 0,923804 & Mean dependent var & 46712,40 \\
Adjusted R-squared & 0,909517 & S.D. dependent var & 44795,29 \\
S.E. of regression & 13474,59 & Akaike info criterion & 22,03186 \\
Sum squared resid & $2,91 E+09$ & Schwarz criterion & 22,23100 \\
Log likelihood & $-216,3186$ & Hannan-Quinn criter. & 22,07073 \\
F-statistic & 64,66148 & Durbin-Watson stat & 1,067699
\end{tabular}


Prob(F-statistic) $\quad 0,000000$

Sumber: Output Eviews9 data diolah (2019)

Berdarkan hasil olahan data dengan analisis berganda melalui program Eviews 9 di dapat persamaan berikut:

$$
\begin{array}{rrr}
\hat{Y}_{i}= & -261833,0+-0,189227 X 1_{i}+0,159282 X 2_{i}+0,949667_{i} \\
& (-6,260825) \quad(-1,338016) \quad(2,922586) & (5,247312)
\end{array}
$$

1. Rata-rata tarif hotel Kabupaten Kerinci $\left(\mathrm{X}_{1}\right)$

Variabel rata-rata tarif hotel Kabupaten Kerinci mempunyai koefisien regresi sebesar -0,189227 memberikan arti bahwa rata-rata tarif hotel Kabupaten Kerinci $\left(\mathrm{X}_{1}\right)$ berpengaruh negatif terhadap kunjungan wisatawan nusantara asal Kota Jambi dan besar probabilita 0,1996 tidak signifikan pada $\alpha=10 \%$. Hal ini menunjukkan bahwa setiap penurunan satu rata-rata tarif hotel Kabupaten Kerinci akan terjadi penurunan wisnus sebesar 0,189227 dengan asumsi variabel lainnya tetap atau konstan (ceteris paribus).

2. Jumlah kendaraan pribadi Kota Jambi $\left(\mathrm{X}_{2}\right)$

Variabel jumlah kendaraan pribadi Kota Jambi mempunyai koefisien regresi sebesar 0,159282 memberikan arti bahwa jumlah kendaraan pribadi Kota Jambi $\left(\mathrm{X}_{2}\right)$ berpengaruh positif terhadap kunjungan wisatawan nusantara asal Kota Jambi dan besar probabilita 0,0100 signifikan pada $\alpha=5 \%$. Hal ini menunjukkan bahwa setiap penambahan satu kunjungan wisatawan nusantara asal Kota Jambi ke TNKS Kerinci akan terjadi kenaikan wisnus sebesar 0,159282 dengan asumsi variabel lainnya tetap atau konstan (ceteris paribus).

3. Jumlah penduduk produktif Kota Jambi $\left(\mathrm{X}_{3}\right)$

Variabel jumlah penduduk produktif Kota Jambi $\left(\mathrm{X}_{3}\right)$ mempunyai koefisien regresi sebesar 0,949667 memberikan arti bahwa jumlah penduduk produktif Kota Jambi $\left(\mathrm{X}_{3}\right)$ berpengaruh positif terhadap kunjungan wisatawan nusantara asal Kota Jambi dan besar probabilita 0,0001 signifikan pada $\alpha=5 \%$. Hal ini menunjukkan bahwa setiap terjadi peningkatan satu orang jumlah penduduk produktif Kota Jambi akan terjadi peningkatkan kunjungan wisatawan nusantara asal Kota Jambi sebesar 0,949667 dengan asumsi variabel lainnya tetap atau konstan (ceteris paribus).

\section{Pengujian Hipotesis \\ Uji F-Statistik}

F hitung sebesar 64,66148 dengan probabilitas sebesar $(0,000000)$ atau lebih kecil dari $\alpha=0,05(0,000000<0,05)$ maka $\mathrm{H}_{\mathrm{o}}$ ditolak dan $\mathrm{H}_{\mathrm{a}}$ diterima. Artinya secara simultan atau bersama-sama terdapat pengaruh yang signifikan antara rata-rata tarif hotel Kerinci, jumlah kendaraan pribadi Kota Jambi, dan jumlah penduduk produktif Kota Jambi terhadap kunjungan wisatawan nusantara asal Kota Jambi ke TNKS Kerinci.

\section{Uji Parsial (Uji T)}

Hasil regresi menunjukkan variabel $\mathrm{X}_{1}$ (rata-rata tarif hotel kerinci) dapat dilihat bahwa nilai t hitung sebesar -1,338016 dengan probabilita sebesar 0,1996 atau lebih besar dari nilai $(0,1996<0,10)$, maka $\mathrm{H}_{\mathrm{o}}$ diterima dan $\mathrm{H}_{\mathrm{a}}$ ditolak. Dari hasil tersebut dapat disimpulkan bahwa variabel rata-rata tarif hotel kerinci tidak berpengaruh signifikan terhadap kunjungan wisatawan nusantara asal Kota Jambi ke TNKS Kerinci.

Variabel $\mathrm{X}_{2}$ (jumlah kendaraan pribadi Kota Jambi) dapat dilihat bahwa nilai $\mathrm{t}$ hitung sebesar 2,922586 dengan probabilita variabel jumlah kendaraan pribadi Kota Jambi sebesar 0,0100 atau lebih kecil dari nilai $\alpha=0,05(0,0100<0,05)$, maka $\mathrm{H}_{\mathrm{o}}$ ditolak dan $\mathrm{H}_{\mathrm{a}}$ diterima. Dari hasil tersebut dapat disimpulkan bahwa variabel jumlah 
kendaraan pribadi Kota Jambi secara individu memiliki pengaruh signifikan terhadap kunjungan wisatawan nusantara asal Kota Jambi ke TNKS Kerinci.

Variabel $\mathrm{X}_{3}$ (jumlah penduduk produktif Kota Jambi) dapat dilihat nilai t hitung sebesar 5,247312 dengan probabilita variabel jumlah penduduk Kota Jambi sebesar 0,0001 atau lebih kecil dari nilai $\alpha=0,05(0,0000<0,05)$, maka $\mathrm{H}_{\mathrm{o}}$ ditolak dan $\mathrm{H}_{\mathrm{a}}$ diterima. Dari hasil tersebut dapat disimpulkan bahwa variabel jumlah penduduk produktif Kota Jambi secara individu memiliki pengaruh signifikan terhadap kunjungan wisatawan nusantara asal Kota Jambi ke TNKS Kerinci.

\section{Koefisien Determinasi $\left(\mathbf{R}^{2}\right)$}

Pengaruh variabel bebas rata-rata tarif hotel Kerinci $\left(\mathrm{X}_{1}\right)$, jumlah kendaraan pribadi Kota Jambi $\left(\mathrm{X}_{2}\right)$, dan jumlah penduduk produktif Kota Jambi $\left(\mathrm{X}_{3}\right)$ terhadap variabel terikat jumlah kunjungan wisatawan nusantara asal Kota Jambi ke TNKS Kerinci (Y) ditunjukkan oleh besar koefisien determinasi $\mathrm{R}^{2}$. Diperoleh angka $\mathrm{R}$ squared sebesar 0,923804 atau 92\%. Artinya, variabel bebas rata-rata tarif hotel Kerinci $\left(\mathrm{X}_{1}\right)$, jumlah kendaraan pribadi Kota Jambi $\left(\mathrm{X}_{2}\right)$, dan jumlah penduduk produktif Kota Jambi $\left(\mathrm{X}_{3}\right)$ sebesar $92,38 \%$ dapat menjelaskan variabel terikat, sedangkan 7,62\% dijelaskan oleh variabel lain selain yang diteliti.

\section{Uji Asumsi Klasik}

\section{Uji Multikolinearitas}

Untuk mengetahui adanya korelasi linier antar variabel bebas dalam model empiris. Multikolinearitas dapat dilihat juga dari tolerance and variance inflation factors (VIF). Berikut ini model multikolinearitas dapat dilihat pada tabel 2:

Tabel 2. Hasil Variance Inflation Factor (VIF)

Variance Inflation Factors

Date: 07/11/19 Time: 13:41

Sample: 19982017

Included observations: 20

\begin{tabular}{cccc}
\hline \hline Variable & $\begin{array}{c}\text { Coefficient } \\
\text { Variance }\end{array}$ & $\begin{array}{c}\text { Uncentered } \\
\text { VIF }\end{array}$ & $\begin{array}{c}\text { Centered } \\
\text { VIF }\end{array}$ \\
\hline \hline C & $1,75 \mathrm{E}+09$ & 192,6568 & NA \\
X1 & 0,020001 & 105,9632 & 3,410887 \\
X2 & 0,002970 & 3,918625 & 2,276175 \\
X3 & 0,032754 & 462,7550 & 5,478336 \\
\hline \hline
\end{tabular}

Sumber: Output Eviews 9 data diolah, 2019

Hasil tersebut terlihat bahwa VIF dari setiap variabel tidak mengandung multikolinieritas, dimana nilai VIF $\mathrm{X}_{1}$ sebesar 3,410887 < 10 berarti $\mathrm{X}_{1}$ tidak mengandung multikolinieritas. Variabel $\mathrm{X}_{2}$ memiliki nilai sebesar 2,276175 < 10 berarti variabel $\mathrm{X}_{2}$ tidak mengandung multikolinieritas. Variabel $\mathrm{X}_{3}$ memiliki nilai sebesar $5,478336<10$ berarti $X_{3}$ tidak mengandung multikolinieritas. Dapat disimpulkan bahwa pengujian ini terbebas dari gejala multikolinieritas. 


\section{Uji Heterokedastisitas}

Untuk menguji masalah heterokedastisitas pada model ini maka digunakan pengujian Breusch-Pagan-Godfrey. Jika terjadi heterokedastisitas maka penaksir OLS tetap tak bias atau konsisten, tetapi penaksir tadi tidak lagi efisien baik dalam sampel kecil maupun besar. Berikut ini model heterokedastisitas dapat dilihat pada tabel 3:

Tabel 3. Hasil regresi heterokedastisitas

Heteroskedasticity Test: Breusch-Pagan-Godfrey

F-statistic

0,530687 Prob. $\mathrm{F}(3,16)$

0,6677

Obs*R-squared

1,809978 Prob. Chi-Square(3)

0,6128

Scaled explained SS

0,613724 Prob. Chi-Square(3)

0,8933

Sumber: Output Eviews 9 data diolah, 2019

\section{Uji Autokorelasi}

Autokorelasi adalah yang terjadi dalam satu variabel. Korelasi ini terjadi antar waktu atau individu. Umumnya kasus autokorelasi banyak terjadi pada data time series, artinya kondisi sekarang dipengaruhi waktu yang lalu. Berikut hasil dan penjelasannya:

Tabel 4. Hasil regresi autokorelasi

Breusch-Godfrey Serial Correlation LM Test:

$\begin{array}{llll}\text { F-statistic } & 2,136895 & \text { Prob. F(2,14) } & 0,1549 \\ \text { Obs*R-squared } & 4,677508 & \text { Prob. Chi-Square(2) } & 0,0964\end{array}$

Sumber: Output Eviews data diolah, 2019

Hasil yang terdapat menunjukkan bahwa probability dari $\mathrm{Ob}^{*} \mathrm{R}$-squared dilihat dari Chi-Square(2) sebesar 0,0964 nilai ini jauh lebih besar dari $\alpha=0,05$ yang mengindentifikasikan bahwa model ini tidak mengandung masalah autokorelasi.

\section{Uji Normalitas}

Uji yang dilakukan untuk mengevaluasi apakah nilai variabel pengganggu dari model yang dibentuk sudah normal atau tidak. Konsep pengujian uji normalitas menggunakan pendekatan Jorque-Berra test.
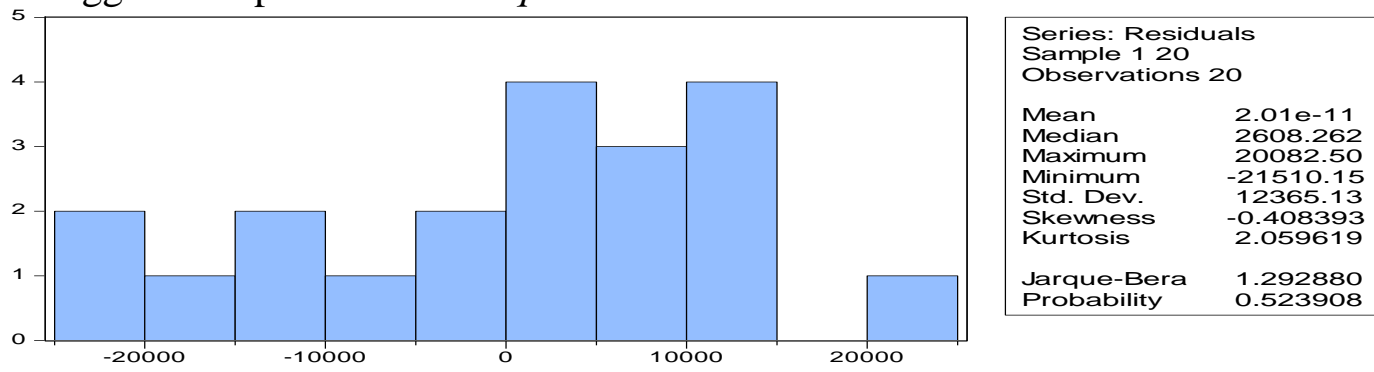

Gambar.1. Uji normalitas

Hasil grafik uji normalitas menunjukkan bahwa nilai probabilita J-B hitung sebesar 0,523908 $>0,05 \alpha=5$ persen, sehingga data tersebut berdistribusi normal.

Pengaruh rata - rata tarif hotel Kabupaten Kerinci terhadap kunjungan wisatawan nusantara asal Kota Jambi ke objek wisata alam TNKS Kerinci

Dari peenelitian ini diketahui bahwa rata-rata tarif hotel Kabupaten Kerinci berpengaruh negatif dan tidak signifikan terhadap kunjungan wisatawan nusantara asal Kota Jambi ke TNKS di Kerinci. 
Pengaruh jumlah kendaraan pribadi terhadap kunjungan wisatawan nusantara asal Kota Jambi ke objek wisata alam TNKS Kerinci

Jumlah kendaraan pribadi Kota Jambi $\left(\mathrm{X}_{2}\right)$ berpengaruh positif dan signifikan terhadap kunjungan wisatawan nusantara asal Kota Jambi ke TNKS Kabupaten Kerinci, merupakan sarana yang menyebabkan wisatawan dapat mengunjungi objek wisata alam TNKS Kabupaten Kerinci.

Pengaruh jumlah penduduk produktif terhadap kunjungan wisatawan nusantara asal Kota Jambi ke objek wisata alam TNKS Kerinci

Variabel jumlah penduduk produktif Kota Jambi $\left(\mathrm{X}_{3}\right)$ berpengaruh positif dan signifikan terhadap peningkatan demand terhadap kebutuhan atau konsumsi jasa hiburan.

\section{Nilai kesediaan membayar/WTP wisatawan nusantara asal Kota Jambi}

Metode ini diterapkan dengan tehnik terhadap 39 orang pengunjung pariwisata alam Kota Jambi ke TNKS Kabupaten Kerinci Provinsi Jambi, yakni proporsi 39 pengunjung di objek wisata desa Kersik Tuo. Desa Kersik Tuo merupakan gerbang masuk utama entry point lokasi pariwisata alam TNKS Kabupaten Kerinci. Penerapan pendekatan nilai kontingensi ini dilakukan dengan mengajukan pertanyaan kepada responden tentang berapa nilai kesediaan mereka membayar WTP untuk tetap dapat menikmati jasa pariwisata alam yang disediakan di TNKS Kabupa ten Kerinci. Berikut ini penjelasannya:

Tabel 5. Nilai kesediaan membayar/WTP responden pengunjung

\begin{tabular}{|c|c|c|c|c|c|c|}
\hline $\begin{array}{l}\text { Nilai WTP } \\
\text { (Rp/orang) }\end{array}$ & $\begin{array}{c}\text { Rata-rata } \\
\text { interval } \\
\text { nilai WTP } \\
\text { (Rp) }\end{array}$ & $\begin{array}{l}\text { Pengunjung } \\
\text { (orang) }\end{array}$ & $\begin{array}{c}\text { Prosentase } \\
\text { Kumulatif } \\
\qquad(\%)\end{array}$ & $\begin{array}{c}\text { Proporsi } \\
\text { Pilihan } \\
\text { jumlah } \\
\text { pengunjung } \\
\text { (orang/tahun) } \\
\end{array}$ & $\begin{array}{c}\text { Jumlah } \\
\text { WTP } \\
\text { (Rp) }\end{array}$ & $\begin{array}{c}\text { Jumlah } \\
\text { kumulatif } \\
\text { nilai WTP } \\
\text { (Rp) }\end{array}$ \\
\hline $\mathbf{1}$ & 2 & 3 & 4 & 5 & 6 & 7 \\
\hline 0-249 & 125 & 9 & 100 & 351 & 12.500 & 12.500 \\
\hline $250-499$ & 375 & 7 & 93 & 273 & 34.875 & 47.375 \\
\hline $500-749$ & 625 & 6 & 87 & 234 & 54.375 & 101.750 \\
\hline 750-999 & 875 & 5 & 82 & 195 & 71.750 & 173.500 \\
\hline $1.000-1.249$ & 1.125 & 4 & 78 & 156 & 87.750 & 261.250 \\
\hline $1.250-1.499$ & 1.375 & 1 & 77 & 39 & 105.875 & 367.125 \\
\hline $1.500-1.999$ & 1.875 & 3 & 74 & 117 & 138.750 & 505.875 \\
\hline $2.000-2.249$ & 2.125 & 1 & 73 & 39 & 155.125 & 661.000 \\
\hline $2.250-2.749$ & 2.625 & 2 & 71 & 78 & 186.375 & 847.375 \\
\hline $2.750-3.000$ & 2.875 & 1 & 70 & 39 & 201.250 & 1048.625 \\
\hline \multicolumn{6}{|c|}{ TOTAL } & 4.026 .375 \\
\hline
\end{tabular}

Sumber: Data primer diolah, 2019

Total kumulatif nilai kesediaan membayar/WTP pengunjung untuk tetap dapat menikmati jasa pariwisata alam dimaksud sebesar Rp.4.026.375,- dengan rata-rata nilai kesediaan membayar/WTP sebesar Rp. 2647,18,- per orang.

\section{KESIMPULAN DAN SARAN}

\section{Kesimpulan}

Berdasarkan hasil dari uraian pada hasil penelitian, maka dapat diambil kesimpulan bahwa perkembangan kunjungan wisatawan nusantara asal Kota Jambi ke TNKS Kerinci selama periode 1998-2017 mengalami fluktuasi disetiap tahunnya, ratarata kunjungan wisatawan nusantara asal Kota Jambi ke TNKS Kerinci sebesar 24,82\% per tahun. Perkembangan rata-rata tarif hotel Kerinci rata-ratanya sebesar 5,70\% per tahun. Perkembangan jumlah kendaraan pribadi Kota Jambi rata-rata sebesar 22,64\% 
per tahun. Perkembangan jumlah penduduk produktif Kota Jambi rata-rata sebesar $1,80 \%$ per tahun.

Faktor-faktor yang mempengaruhi kunjungan wisatawan nusantara asal Kota Jambi ke objek wisata alam TNKS di Kerinci berdasarkan hasil regresi linier berganda diperoleh hasil secara simultan atau bersama-sama, rata-rata tarif hotel Kabupaten Kerinci, jumlah kendaraan pribadi Kota Jambi dan jumlah penduduk produktif Kota Jambi berpengaruh positif dan signifikan terhadap kunjungan wisatawan nusantara Kota Jambi ke objek wisata alam TNKS Kabupaten Kerinci. Secara parsial rata-rata tarif hotel Kabupaten Kerinci berpengaruh negatif dan tidak signifikan terhadap kunjungan wisatawan nusantara asal Kota Jambi ke objek wisata alam TNKS Kabupaten Kerinci, sedangkan jumlah kendaraan pribadi Kota Jambi dan jumlah penduduk produktif Kota Jambi berpengaruh positif dan signifikan terhadap jumlah kunjungan wisatawan nusantara Kota Jambi ke objek wisata alam TNKS Kabupaten Kerinci.

Nilai kesediaan membayar/WTP Wisatawan Nusantara asal Kota Jambi ke objek wisata alam TNKS Desa Kersik Tuo Kecamatan Kayu Aro Kabupaten Kerinci tercatat sebesar Rp. 4.026.375,- dengan rata-rata sebesar Rp. 2.647,- per orang.

\section{Saran}

Berdasarkan hasil penelitian yang telah diuraikan dan kesimpulan yang diperoleh penulis mengajukan beberapa saran untuk meningkatkan kunjungan wisatawan ke TNKS perlu dilakukan kegiatan promosi jasa wisata secara intensif terutama menyangkut hal yang unik dan spesifik flora dan fauna TNKS atau jasa wisata alam lainnya. Serta pengenalan objek wisata angkutan wisata (seperti kuda dari penginapan ke objek wisata alam yang ada di Desa Kersik Tuo).

Guna lebih meningkatkan daya saing, penggunaan alat transportasi dari Kota Jambi ke TNKS perlu dipertimbangkan sarana angkutan yang lebih nyaman dan biaya murah, dan langsung ke wilayah Desa Kersik Tuo ke kawasan objek gunung Kerinci dan lain sebagainya.

Pemerintah daerah setempat dan semua pemangku kepentingan pengembangan objek wisata alam TNKS memiliki kesediaan membayar yang relatif bagus karena mereka masih dapat langsung secara nyata menikmati kenyamanan kunjungan dan keindahan lingkungan.

\section{DAFTAR PUSTAKA}

Afifah, Nur Kurniasih. (2013). Analisis Willingness To Pay Jasa Lingkungan Air untuk Konservasi di Taman Wisata Alam Kerandangan Kabupaten Lombok Barat Provinsi Nusa Tenggara Barat. Skripsi. Program Magister Ilmu Lingkungan Program Pasca Sarjana. Universitas Diponegoro: Semarang.

Amir, Junaidi, Yulmardi. (2009). Metodologi Penelitian Ekonomi dan Penerapannya. IPB press.

Anonim. (2018). Buku Informasi TNKS. Penerbit Unesco: Kerinci.

Badan Pusat Statistik. (2017). Kota Jambi Dalam Angka 2017. BPS: Kota Jambi.

Badan Pusat Statistik. (2017). Indonesia Dalam Angka 2017. BPS: Indonesia.

Dinas Kebudayaan dan Pariwisata Taman Nasional Kerinci Seblat. (2017). Statistik Pariwisata Provinsi Jambi.

Irma Afia Salma dan Indah Susilowati. (2004). Analisis Permintaan Objek Wisata Alam Curug Sewa, Kabupaten Kendal Dengan Pendekatan Travel Crost. Jurnal Dinamika Pembangunan (JDP). Vol: 1 No: 2 Hal 153-165.

Putra, Dwi Hermawan. (2010). Evaluasi Ekonomi Lingkungan Objek Wisata Pantai Teleng Ria dengan Metode Pendekatan Biaya Perjalanan Travel Cost di 
Kabupaten Pacitan. Skripsi. Jurusan Ekonomi Pembangunan Fakultas Ekonomi Universitas Sebelas Maret: Surakarta.

Safri, Muhammad. (2003). Dampak Pariwisata Alam Taman Nasional Kerinci Seblat Terhadap Ekonomi Massyarakat Sekitar dan Wilayah Kabupaten Kerinci Provinsi Jambi. Riset. IPB: Bogor.

Spillane, JJ. (2004). Pariwisata Indonesia Sejarah dan Prospeknya. Yogyakarta: Kanisius. 